\title{
Sustainable management of municipal solid waste: a systematic approach and legal challenges
}

\author{
Natalia Vedysheva ${ }^{1, *}$, Maria Mukhlynina ${ }^{2}$, Elena Vinogradova $^{2}$, Andrey Nikiforov $^{3}$, and \\ Olga Efimova ${ }^{4}$ \\ ${ }^{1}$ Kutafin Moscow State Law University, 9, Sadovaya-Kudrinskaya str., 125993Moscow, Russia \\ ${ }^{2}$ Institute of State and Law of the Russian Academy of Sciences, 10, Znamenka str., 119019 \\ Moscow, Russia \\ ${ }^{3}$ Moscow State Institute of International Relations (University) of the Ministry of Foreign Affairs of \\ the Russian Federation, 76, Vernadskogo prospect, 119454 Moscow, Russia \\ ${ }^{4}$ Moscow City Pedagogical University, 4, K. 1, 2nd Agricultural passage, 129226 Moscow, Russia
}

\begin{abstract}
The problem of sustainable management of municipal solid waste at the legal and organizational levels both in the Russian Federation and in the world is now coming to the fore and requires immediate solutions. After analyzing the documents of strategic planning and other normative legal acts, the authors of the article attempt to consider current legal problems in the field under study in an interesting aspect of the modern state environmental policy of Russia, which implements the UN sustainable development goals in the environmental direction. The authors make judgments that a successful environmental policy aimed at achieving the UN sustainable development goals in the field of waste management and production is possible only if a systematic approach to the implementation of environmental legislation is implemented and should be based on the principles of efficiency, expediency, and others. In conclusion, a number of conclusions are drawn about the legal acts adopted in the Russian Federation and the organizational measures implemented to help solve various problems related to the sustainable development of the most important segment of the economy and the environment - waste disposal and recycling, reducing their volume and the possibility of secondary use.
\end{abstract}

\section{Introduction}

One of the trends in modern international legislation is the implementation of the principles of sustainable development proclaimed by the UN sustainable development policy and implemented by the natural resources, environmental, land, urban planning and other legislation of Russia $[1,2,11,12]$. Two sustainable development goals (hereinafter - sdgs) goals 11 and 12 (cities and localities, responsible consumption and production), as well as solutions to a number of environmental problems in the field of waste management, the

\footnotetext{
*Corresponding author: veda120006@yandex.ru
} 
Russian Federation in strategic planning documents provides for the development of a sustainable waste management system, including solid municipal waste.

Every year, Russia generates more than 60 million tons of municipal solid waste (hereinafter referred to as MSW) - a figure in itself frightening. A minuscule percentage of 60 million tons is reused, namely, 7-8\%. The rest of the garbage is sent for disposal [3]. Such a low percentage of recycling was primarily due to the lack of infrastructure for separate collection, disposal, and disposal of waste (243 waste disposal complexes, 53 waste sorting complexes, and about 40 incineration plants), as well as the lack of objective accounting for the specific mass of waste received. The problem of a huge number of different classes of waste that is not involved in secondary circulation, but is taken out and placed in landfills, leads to a reduction in the country's agricultural land. Approximately 15 thousand state - sanctioned landfills or, more precisely, MSW disposal facilities occupy an area of approximately 4 million hectares, and this area increases annually by 300-400 thousand hectares [4]. There is an increase in the population's consumption of goods that, after losing their consumer properties, belong to MSW, the amount of packaging waste has increased, and the financing of the industry for their involvement in turnover has decreased. State bodies in the implementation of environmental, land, sanitary and epidemiological surveillance have identified and are detecting contamination and littering of land, pollution of upper aquifers with toxic substances, atmospheric air during the release of biogas, fire and smoke from landfills [5].

In addition to the basic law of Russia, the legal basis for sustainable waste management is a number of international normative legal acts, such as the UN Millennium Declaration, as well as a document adopted following one of the UN conferences "the Future we want", which discussed the policy of sustainable development and others. A significant role in regulating the issues under study was Played by the decree of the head of Russia dated 20.04.2014 No. 259 "On approval Of the concept of state policy of the Russian Federation in the field of international development assistance", however, according to the researcher V. N. Kharkiv [6] 2014 can be described as a time that demonstrates in Russia the tendency to reduce the level of implementation of strategic environmental development goals from the level of internationally significant sustainable development goals recorded back in Rio in 1992 to the level of national significance of environmental security goals.

The study of legal and organizational problems of system sustainable management of MSW in our country is reflected in the works of Vedysheva N. O., Mukhlynina M. M., Redikultceva E. N., Vinogradova E. V., Nikiforov A. I., Mukhlynin D. N., Solovyeva N. V., Lebedeva O. E., Martynova R. F. [1,11,12], Avdonina A.M., Nikiforov A. I. [2], Kharkiv V. N. [6] and others.

\section{Methods}

The methodological basis of the research was made up of General scientific methods, so the analysis and synthesis were used to study existing theoretical and methodological approaches and provisions, as well as to carry out scientific research in the field of nature protection from waste pollution.

The information base of the article consists of normative legal acts, documents of state authorities and their officials, scientific works of scientists on the problems of improving forest protection in modern conditions $[1,2,6,11,12]$. 


\section{Results and discussion}

Despite the reform launched in 2019, the problem of MSW management remains relevant, even problematic in some regions of the Russian Federation (Magadan region, Omsk region, Krasnodar territory, Jewish Autonomous region, etc.). more than $90 \%$ of waste is still sent to landfills and landfills that do not meet the requirements of environmental legislation. According to experts, the targets set in this area (to ensure $100 \%$ sorting of waste by 2030 and a two-fold reduction in the volume of waste sent to the landfill) will not be able to be met. Back in 2018, the accounting chamber of Russia conducted an expert and analytical analysis of the effectiveness of indicators of the state program "environmental protection" [7] aimed at ensuring safe management of MSW, which showed that in some regions the capacity of landfills is almost exhausted, and the infrastructure for waste management is not created. At the current rate of growth of MSW volumes (1-2\% per year) in 32 regions, their capacity will be exhausted by 2024, and in 17 regions of the Russian Federation - by 2022; operators for collecting MSW in 19 regions of the Russian Federation may stop providing their services due to low collection of payments from the population.

To overcome the identified legal and organizational problems in the field of waste management, as well as to solve environmental, social, and economic problems in a comprehensive manner, and to develop the legal framework for public relations in this area in terms of creating an effective management system; development of infrastructure for separate collection, disposal, neutralization, and placement in compliance with all environmental and sanitary-epidemiological requirements, Russia introduces economic incentives for the population, as well as economic entities that use recycled and secondary resources. According To The decree of the President of the Russian Federation, the national project "Ecology" is being implemented, which provides for the Federal projects "Clean country", "Integrated MSW management system" and others. The key tasks are the elimination of unauthorized landfills identified on January 1, 2018 within the borders of cities and an increase in the share of MSW sent for disposal and processing. The project passport defines control and financial indicators. By 2024, the share of MSW planned for disposal of the total volume of generated waste should be $36 \%$, the share of processed waste $-60 \%$. Another important step on the way to achieving the planned indicators is 7 new production and technical complexes for waste of hazard classes I and II that have been put into operation. These projects are allocated 420, 1 billion rubles. RUB [8]. The reform in the field of waste management, which began in 2019, has been fully launched in Russia, which involves the creation of regional operators engaged in the treatment of MSW in the territories of the country's constituent entities.

By April 2019, according to the head of Ministry of Russia, more than $80 \%$ of subjects switched to a new management model, selected 241 regional operator of the 262 areas of activities started to work 196 regional operators. Projects are being implemented to create a closed-loop economy in 7 regions of the Russian Federation that differ in economic, geographical, and demographic indicators (Yamal, Novosibirsk, Tomsk, Sverdlovsk, and Belgorod regions, the Altai Republic, and Chechnya). At the regional level, the constituent entities of the Russian Federation are also able to adopt regulatory legal acts and exercise their powers in the field of waste management. The legislative consolidation of economic incentives provided for by such acts for regional operators is to some extent intended to contribute to a positive result $[9,13,14]$.

To date, however, the problems identified with the introduction of regional operator (not a transparency process), with the adoption of territorial plans (sometimes without public discussion, with the lack of correct statistical data, calculation standards for waste accumulation, etc.), determination of tariffs. These and other violations of both state bodies and regional operators are recorded in court practice $[10,15,16,17]$. Problems include: 
- territorial schemes often lack information about legal entities and individual entrepreneurs;

- an unregulated procedure for collecting expenses incurred by the regional operator from the owners of land plots where unauthorized waste is located;

- it is difficult to implement the project of certification of landfills that need to be reclaimed in the regions of the Russian Federation, etc.

\section{Conclusions}

To address the identified legal and organizational problems of sustainable management of MSW the state uses mainly economic incentives, for example, it would be advisable to legislate state support for companies (in the form of tax breaks, investment, preferential loans and other economic incentives) that deal with resource conservation, active use of secondary resources, engage TCR in the economic turnover. However, stimulating the manufacturer is not a sufficient measure, it is necessary to encourage the population to use multi - turn goods and packaging.

Considerable hopes are currently placed on the "Russian environmental operator", the functions and powers of the company's founder on behalf of the Russian Federation are now performed by the Ministry of natural resources of Russia. This company is designed to help all state bodies, both at the Federal and regional levels, to exercise their powers in the field of waste management, and the public - the right to reliable information about the state of the environment, in terms of handling MSW.

It is necessary to further improve the legislation regulating the management of municipal solid waste. We agree with the opinion of V. N. Kharkiv, who correctly noted that all normative legal documents are United by the recognition of the principles of sustainable development as a strategic direction for the development of mankind [6]. Indeed, the rational use of natural resources and environmentally friendly methods of waste disposal and recycling is an important task and is one of the world's most acute problems that require urgent fundamental study and solution.

\section{References}

1. M. Mukhlynina, N. Vedysheva, Actual Problems of Ecology and Environmental Management: Cooperation for Sustainable Development and Environmental Safety, APEEM 2020., 05003 (2020);

2. A.M. Avdonina, A.I. Nikiforov Economics of sustainable development, 4(36), 94 (2018).

3. Order of the Ministry of natural Resources of the Russian Federation of 14.08.2013 No. 298 "On approval of a comprehensive strategy for handling solid municipal (household) waste in the Russian Federation", Rationing in construction and housing, No. 4, 2013.

4. Decree of the President of the Russian Federation of 19.04.2017 No. 176 "On the strategy of environmental safety of the Russian Federation for the period up to 2025", item 11, Collection of legislation of the Russian Federation, 24.04.2017, No. 17, article 2546.

5. State report "On the state and environmental protection of the Russian Federation in 2017", State (national) report "On the state and use of land in the Russian Federation in 2017", www.mpr.gov.ru; www.rosreestr.ru

6. V.N. Kharkiv, Environmental law, 4, 3 (2019). 
7. Report on the work of the accounting chamber of the Russian Federation for 2018, http: // www. ach.gov.ru.

8. Passport of the national project "Ecology" (approved by the Presidium of the presidential Council for strategic development and national projects, Protocol No. 16 of 24.12.2018), http://www.consultant.ru

9. Regional law of Leningrad region from 19.03.2020 No. 29-oz "On establishment of tax rate for tax on profit of organizations for the organizations having the status of a regional operator of municipal solid waste management on the territory of the Leningrad region", http://www.consultant.ru

10. The appeal determination of Judicial Board on administrative cases of the Supreme Court of the Russian Federation from 04.04.2019 No. 36-АПА19-3

11. A.I. Nikiforov, M.M. Mukhlynina, N.O. Vedysheva, E.N. Redikultceva, R.F. Martynova, International Journal of Engineering and Advanced Technology (IJEAT), 5, 2251 (2019);

12. E.V. Vinogradova, M.M. Mukhlynina, D.N. Mukhlynin, N.V. Solovyeva, O.E. Lebedeva, Journal of Environmental Management and Tourism. , 1 (25) 144 (2018)

13. Decree of the Cabinet of Ministers of the Republic of Adygea 19.05.2017 No. 89 "About Rules of implementation of activities of the regional operators for municipal solid waste management", http://www.consultant.ru

14. Decision of Council of Ministers of the Republic of Crimea of 29.06.2020 No. 375 "On approval of territorial plans in the area of waste management, including solid municipal waste in the Republic of Crimea", http: // www.consultant.ru

15. The Appeal determination of Judicial Board on administrative cases of the Supreme Court of the Russian Federation from 20.03.2019 No. 51-АПА19-3

16. The Appeal determination of Judicial Board on administrative cases of the Supreme Court of 28.11.2018 No. 87-АПГ18-10

17. The Appeal determination of Judicial Board on administrative cases of the Supreme Court of 21.11.2018 No. 7-АПГ18-8. 